\title{
COMPARATIVE ENERGY AND EXERGY ANALYSIS OF A POWER PLANT WITH SUPER-CRITICAL AND SUB-CRITICAL
}

\author{
Burhanettin Çetin ${ }^{1, *}$, Erman Ozen ${ }^{1}$
}

\begin{abstract}
The aim of this study that how to effect live steam parameters reheat and feed water preheater numbers on efficiencies of energy and exergy at coal-fired power plants. Moreover, two desuperheaters and a regenerative turbine are added USCPP (Case 3) to approach best results. Soma Power Plant (Case 1) consists of one reheat stage, two HPRHs and four LPRHs with one DEA. It is operated sub-critic and coal is used for a fuel. Live steam conditions of Soma Power Plant set at $13,92 \mathrm{MPa}$ and $540{ }^{\circ} \mathrm{C}$, and the reheat steam is reheated to $540{ }^{\circ} \mathrm{C}$. Supercritical Power Plant (Case 2) consists of the same main components of Case 1. However, steam parameters of Case 2 are increased to $262.5 \mathrm{Bar}$ and $600{ }^{\circ} \mathrm{C}$ to determine impact of the steam parameters on power plant efficiencies. USCPP which consists of two reheat stages, four HPRHs, six LPRHs with one DEA is designed to generate live steam under nominal conditions of $30 \mathrm{Bar}$ and $600{ }^{\circ} \mathrm{C}$. Besides, reheat steam are heated to $620^{\circ} \mathrm{C}$. Simulations have been carried out Ebsilon Professional software and pressure drops at preheaters and reheats are also considered. Some assumptions are made in the analysis. The thermal and exergy efficiencies of USCPP increase by 9.241 and 8.06 percentage points compared with Soma power plant, respectively. The results of this study that live steam parameters which are increased from sub-critical values to super-critical values have enormous influence on energy and exergy efficiencies. Secondly, adding second reheat stage has positive impact to improve power plant efficiencies. Finally, augmenting feed water preheater number, adding two desuperheater and one regenerative turbine increase power plant efficiencies. However, optimum numbers of feed water preheaters are determined considering economic parameters.
\end{abstract}

Keywords: Thermal Efficiency, Exergy Efficiency, Sub-Critical Power Plant, Ultra-Supercritical Power Plant

\section{INTRODUCTION}

Energy is needed for almost every stage of modern life and achieving proper energy gained more attention for both producers and consumers. In addition, the energy consumption level is used as the criteria to indicate the development level of the countries. The level of energy dependency and the quantity of energy consumption in many developed countries are higher than developing countries [1]. On the other hand, global warming has been one issue of great concern in the world. There is very good correlation between the greenhouse gas concentration in atmosphere and the global temperature. $\mathrm{CO}_{2}$ accounts for over $50 \%$ of the contributions of greenhouse gases causing global warming. In the world, 30-40 \% of total $\mathrm{CO}_{2}$ emissions come from coal-fired power plants [2]. Economic power generation with lowest possible fuel consumption is the main challenge for all the engineers working in power generation industry [3].

Energy is also very essential for economic and social development and improved quality of life in Turkey, as in other countries [4]. However, in Turkey, $50 \%$ of the amount of electricity generated from thermal power plants is depended on imported fuel sources, especially natural gas [5]. As a result, energy conservation is extremely significant for energy security, environmental protection, emission and imported fuel reduction in Turkey. Even though Turkey has many power plants in which coal is used as a fuel, they have low thermal and exergy efficiency. For this reason, they have to be renewed to increase their thermal and exergy efficiency. Power plants should be operated at a high parameter condition in supercritical and ultra-supercritical domains to accomplish this goal. Power plant parameters have been enhanced extremely over the past decades. Live steam pressure can reach $30 \mathrm{MPa}$ and live steam temperature has increased to $600{ }^{\circ} \mathrm{C}$ [6]. Therefore, USCPPs can be one of the best choices to decrease external dependence.

Analyses of power generation systems are of scientific interest and also essential for the efficient utilization of energy resources. The most commonly used method for analysis of an energy-conversion process is 
the first law of thermodynamics. Furthermore, exergetic analyses provide a tool for a clear distinction between energy losses to the environment and internal irreversibility in the process [7].

In the literature, there exists a number of paper concerning energetic and exergetic performances of coal-fired thermal power plants. For instance, Aljundi determines the largest energy and exergy losses for AlHussein Power Plant in Jordan by analyzing the system components separately [8]. Huseyin et al. analyzed comparatively the performance of nine thermal power plants under control governmental bodies in Turkey, from energetic and exergetic viewpoint [5]. Doseva and Chakyrova have analyzed energy and exergy analysis of cogeneration system with biogas engines [9]. Wolley et al. have researched effect of waste heat energy at energy efficiency [10]. Karakurt and Gunes show the effect of part load condition at power plant [11]. Akkaya have investigated influence of ambient condition at organic rankine cycle [12]. Ozdil et al. have worked on cogeneration system in food industry [13]. Xu and Zhou investigated thermodynamic and techno-economic analyses at coal-fired power plants by adding outer steam cooer and the regenerative turbine [6]. Oktay analyzed the irreversibilities, exergy efficiency and improvement factor of plant components for a fluidized bed thermal power plant in Turkey [14]. Kaushik has investigated irreversibilities of Brayton cycle based on ecological optimization criterion and analyzed thermo-economic optimization and parametric study of an irreversible regenerative Brayton cycle. Moreover, Kaushik has analyzed efficient power optimization of Brayton heat engine with variable specific heat of the working fluid and investigated energy and exergy analysis of annular thermoelectric heat pump and thermoelectric heat pump $[15,16,17,18,19]$. Rashidi and Aghagoli investigated the first and second law analysis for the cycle and optimization of the thermal and exergy efficiencies by changing turbine inlet pressure, boiler exit steam temperature, and condenser pressure [7]. Li et al. presented thermodynamic analysis and design optimization of a double reheat system in an ultra-supercritical power plant [20]. Reddy et al. investigated appropriate reheat parameters for double reheat units [21]. Adibhatla and Kaushik performed an energetic and exergetic analysis on a $660 \mathrm{MWe}$ coal fired supercritical thermal power plant at $100 \%, 80 \%$ and $60 \%$ of normal continuous rating conditions under constant pressure as well as pure sliding pressure operation [3].

In this paper, three thermal power plants have been analyzed. The objectives of the current study are as follows, (1) to present a single reheat sub-critic power plant with six-stage extractions regenerative heaters (Soma Power Plant); (2) to present a single reheat super-critical power plant with six-stage extractions regenerative heaters; (3) to present a double reheat ultra-super-critical power plants with ten-stage extractions regenerative heaters; (4) to measure energy and exergy efficiency of these power plants. All these three systems, power generation efficiencies, total energy input amounts and exergy efficiency are compared and discussed. This paper aims to show that how to improve power generation efficiency and exergy efficiency at power plants in Turkey with the various steam parameters.

\section{BRIEF INTRODUCTION OF THE THERMAL PERFORMANCE EVALUATION CRITERIA}

Power generation efficiency and heat rate are commonly used in the electric power industry to evaluate thermal performance of power generation units [22]. Based on a coal-fired power plants, the power generation efficiency $\eta_{I}$ is the ratio of $P_{\text {gen }}$ to $E_{\text {total }}$. Heat rate is defined as follows:

$$
q=\left(E_{\text {total }} \times 3600\right) / \mathrm{P}_{\text {gen }}=3600 /\left(\mathrm{P}_{\text {gen }} / E_{\text {total }}\right)=3600 / \eta_{I}
$$

where $E_{\text {total }}$ refers to the total energy input per unit time. Theoretically, $E_{\text {total }}$ is the total energy entering the system, and includes the chemical energy of coal, the energy of air and the energy of makeup water. To simplify the calculation, the quantitative value of $E_{\text {total }}$ is considered as the chemical energy of coal, which equivalent to the low heat value (LHV) of coal input per unit time.

$P_{\text {gen }} \quad$ refers to the power generated by the steam turbine. $E_{\text {total }}$ and $P_{\text {gen }}$ have the same unit of measurement ( $\mathrm{kW}, \mathrm{MW}$, or GW). The number 3600 refers to $3600 \mathrm{~kJ} / \mathrm{kWh}$. The unit of heat rate is $\mathrm{kJ} / \mathrm{kWh}$.

Chemical exergy of fuels calculates constitutive components of fuels. Therefore, Szargut ve Stryrlska develop ' $\varphi$ ' value which refers to fuel exergy rate of fuel lower heating value [23]:

$$
\varphi=B_{0} / H u
$$


where $B_{0}$ refers to fuel exergy value and $H u$ refers to fuel lower heating value. The calculation of $\varphi$ is defined as follow:

$$
\varphi=1,0437+0,1882(h / c)+0,0610(o / c)+0,0404(n / c)
$$

For the exergy of solid fuels $B_{0, \text { solid }}$ is defined as follows:

$$
\begin{gathered}
\left.B_{0, \text { solid }}=\varphi\left(H u+w \cdot h_{f g}\right)\right) \\
B_{g}=B_{0, \text { solid }} \times \dot{m}_{\text {coal }}
\end{gathered}
$$

The exergy efficiency of the power plants $\left(\eta_{I I}\right)$ :

$$
\eta_{I I}=W_{\text {out }} / B_{g}
$$

where $B_{g}$ refers to total exergy input of solid fuel. Analysis of coal used for this study is shown at Table 1 . Besides, LHV of coal is $8350 \mathrm{~kJ} / \mathrm{kg}$ [24].

Table 1. Analysis of coal used for the study

\begin{tabular}{|c|c|c|}
\hline Parameter & Symbol & Percentage of constituent \\
\hline Carbon & $\mathrm{c}$ & 42.75 \\
\hline Hydrogen & $\mathrm{h}$ & 1.60 \\
\hline Nitrogen & $\mathrm{n}$ & 0.50 \\
\hline Oxygen & $\mathrm{o}$ & 22.45 \\
\hline Ash & - & 45.00 \\
\hline Moisture & $\mathrm{w}$ & 20.00 \\
\hline
\end{tabular}

\section{CASE 1 : TYPICAL SUB-CRITIC POWER PLANT WITH SINGLE REHEAT STAGE IN TURKEY (SOMA)}

\section{Configuration of Case 1}

Typical coal-fired power plant with single reheat in Turkey is selected at the Case 1. The simplified process flow diagram of the sub-critic power plant is shown Figure 1. The power output of the single reheat system under turbine heat acceptance load condition is $165 \mathrm{MW}$. The plant consists of turbine stages, two HPRHs, four LPRHs with one DEA, GEN, CON and two FWPs. The live steam conditions are the same of Soma Power Plants. Live steam temperature and pressure are chosen $540{ }^{\circ} \mathrm{C}$ and 139 bar, respectively. The reheated steam is heated at $540{ }^{\circ} \mathrm{C}$ and the exhaust steam pressure of the steam turbine is set to $7.5 \mathrm{kPa}$. The live steam flows HP turbine and the exhaust steam of the HP turbine goes to HPRH1 and boiler to reheat $540{ }^{\circ} \mathrm{C}$. The reheated steam at the boiler flows IP 1 turbine section. The steam is extracted for HPRH1 before going to DEA stage. The steam flows through the LP turbine and goes into the CON. The steam is extracted four times at specific pressures for LPRHs.

\section{System simulation and main assumptions}

In this study, simulations have been carried out Ebsilon Professional software which includes the thermodynamic cycle and energy equilibrium of the thermal systems in the power plant [25]. The following assumptions are made in analysis.

(1) The operation of the power plant is considered to be in a steady state;

(2) The mean isentropic efficiencies of turbine stages and efficiency of boiler for Case 1 are equal 0.85 and 0.85 , respectively; 
(3) In the different stages of the HP, IP and LP turbines, the mean isentropic efficiencies and efficiency of boiler for Case 2-3 are equal to $0.88,0.91,0.87$ and 0.90 , respectively [22];

(4) Efficiency of the generator and pumps for are chosen 0.98 and 0.80 , respectively;

(5) Pressure drop in regenerative heaters: $2 \%$ inlet pressure at steam side, negligible at water side [26];

(6) Pressure drop in reheat stages: $10 \%$ cold side pressure of first and second- stage reheat steam [27].

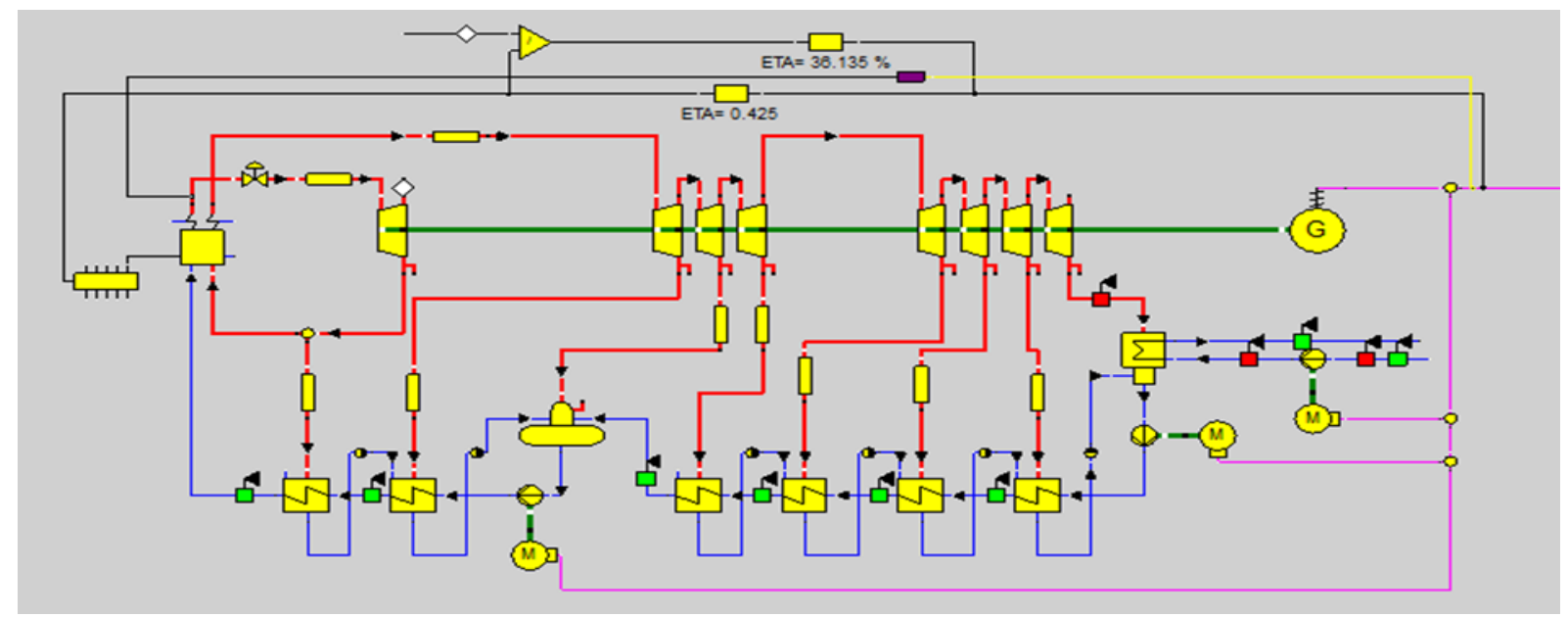

Figure 1. Process diagram of Case 1

\section{CASE 2 : SINGLE REHEAT SYSTEM WITH SIX-STAGE EXTRACTION STEAM Configuration of Case 2}

In this case, efficiencies of the power plant are enhanced by increasing live steam parameters from subcritical values to super-critical values. Figure 2 shows process flow diagram of Case 2. The live steam parameters are set to 262.5 bar and $600{ }^{\circ} \mathrm{C}$, reheat steams are heated to $610{ }^{\circ} \mathrm{C}$. The exhaust steam of HP turbine flows the boiler to reheat and then enters IP 1 turbine. The location of the extraction points are placed according to the basic principle of power plant design. More specifically, the extraction point of HPRH1 is located at the HP turbine exhaust port. The extraction point of HPRH2 is located between HPRH1 and deaerator where is located at IP 1 turbine exhaust port. The extraction points of LPRH3 and LPRH4 are arranged IP 2 turbine. The extraction point of LPRH5 and LPRH6 are located at LP turbine.

The feed-water enthalpy rise of regenerative system is equivalent to each other [22]. The reheat pressure of Case 1 and Case 2 are chosen 31.38 bar and 78.6 bar, respectively. The first and second-stage reheat pressure of Case 3 are chosen 90 bar and 27 bar. Because, the first and second stage reheat pressure are equal to $30 \%$ of the live steam pressure and first reheat pressure, respectively [28].

\section{Process simulation and performance evaluation of Case 2}

Table 2. Energy and exergy performances comparison of Case 1 and Case 2

\begin{tabular}{|c|c|c|}
\hline Performance index & Case 1 & Case 2 \\
\hline Total energy input $(\mathrm{MW})$ & 456.62 & 2279.14 \\
\hline Power output $(\mathrm{MW})$ & 165.00 & 1000.00 \\
\hline Heat rate $(\mathrm{kJ} / \mathrm{kWh})$ & 9962.72 & 8204.90 \\
\hline Decrement in heat rate $(\mathrm{kJ} / \mathrm{kWh})$ & - & 1757.82 \\
\hline Power generation efficiency (\%) & 36.135 & 43.876 \\
\hline Efficiency increment (\%) & - & 7.741 \\
\hline Consumption of coal $(\mathrm{kg} / \mathrm{s})$ & $54.68 *$ & 272.95 \\
\hline Total exergy input $(\mathrm{MW})$ & 523.29 & 2611.90 \\
\hline Exergy efficiency $(\%)$ & 31.53 & 38.28 \\
\hline Exergy efficiency increment $(\%)$ & - & 6.75 \\
\hline
\end{tabular}

$*_{\text {for }} 1000 \mathrm{MW}$ power plant, fuel consumption of Case 1 will be $331.39 \mathrm{~kg} / \mathrm{s}$. 


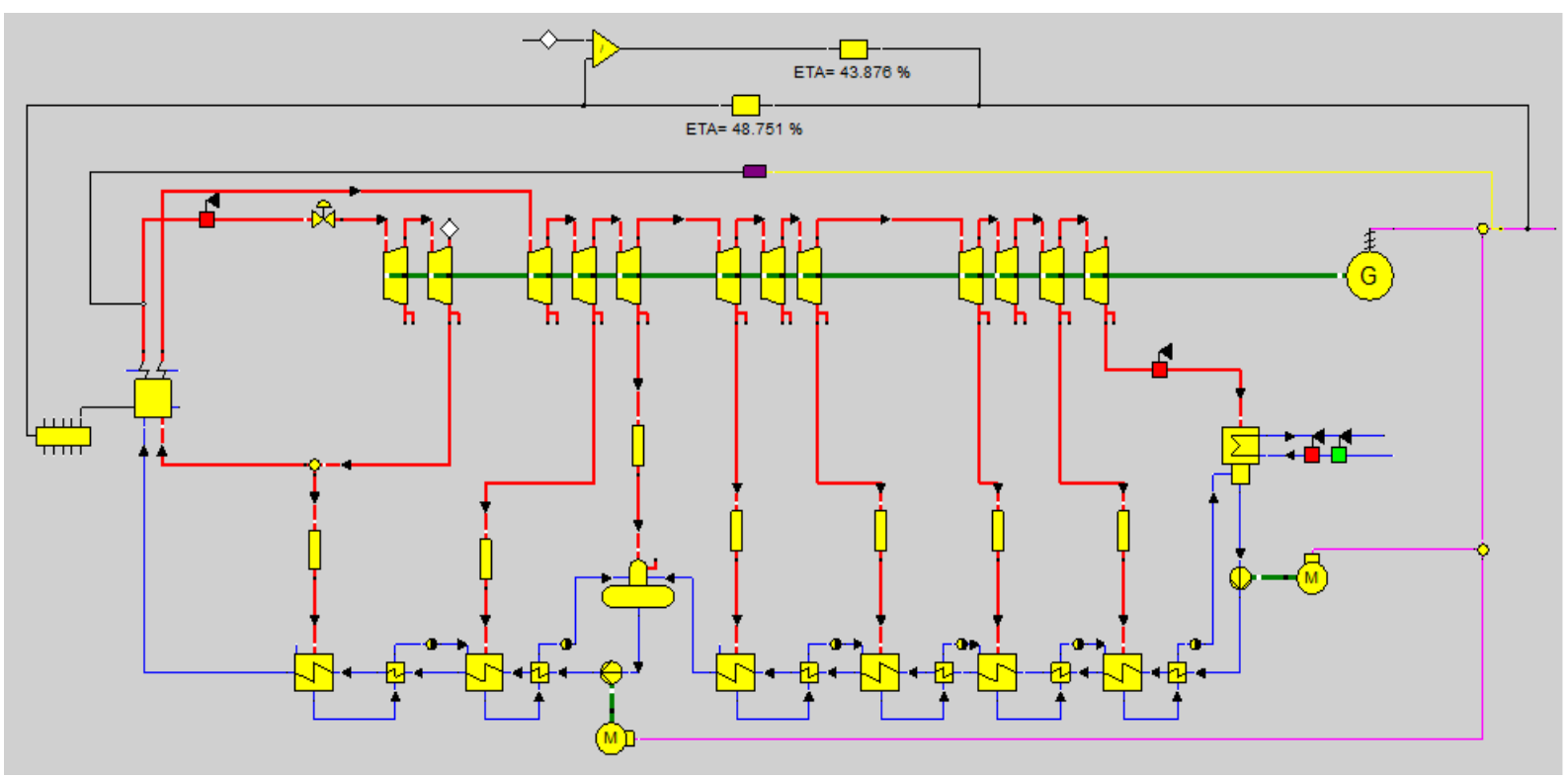

Figure 2. Process diagram of Case 2

The Ebsilon Professional software is used to simulate all the systems in this paper. The thermal and exergy performances Case 1 and Case 2 are compared with Table 2. It is obvious to see that the heat rate of Case 2 decreases $1757.82 \mathrm{~kJ} / \mathrm{kWh}$. The power energy efficiency of Case 2 increases by $7.741 \%$ point compared with that of Case 1. Moreover, exergy efficiency of Case 2 rises $6.75 \%$ point and consumption of fuel reduces 58.44 $\mathrm{kg} / \mathrm{s}$. Rise of the power generation efficiency and reduction of fuel consumption show that release of the $\mathrm{CO}_{2}$ emission decreases.

\section{CASE 3 : DOUBLE REHEAT SYSTEM WITH REGENERATIVE TURBINE AND TWO DESUPERHEATERS}

Reheat technology is one of the outstanding examples, which improves efficiency by increasing mean temperature of the endothermic process. Below the line of T-s diagram represents work out. Because of that, this square is increased by adding second reheat stage compared with the other cases. Efficiency of the Carnot cycle is the reference for all the power plant to optimize. Feed water temperature should be increased before entering the boiler to approach of Carnot cycle efficiency. For this reason, four new regenerative heaters are added to increase final feedwater temperature. Moreover, after first and second reheat stage at the turbines, extraction steams reach high temperature to flow for RHs. Because of that desuperheaters can be used to evaluate this high temperature to increase final feed water temperature. Furthermore, second FWP consumes high electricity to increase boiler feed water pressure after deaerator. It increases feed water pressure from 29 bar to 310 bar. Therefore, regenerative turbine is added the system to generate electricity for second feed water pump. For details, Case 3 consists of double reheat stage, four HPRHs, six LPRHs with one DEA, two desuperheaters and one regenerative turbine. Second reheat steam is heated to $620^{\circ} \mathrm{C}$. Figure 3 illustrates process diagram of Case 3 .

\subsection{Process simulation and performance evaluation of Case 3}

The thermal performance of Case 3 and Case 2 are shown at Table 3. Energy input of Case 3 drops 75.36 MW and power generation efficiency of Case 3 rises $1.50 \%$ points compared with Case 2 . The reason is that final feed water temperature increases to be added desuperheaters and RHs, and also energy consumption of the auxiliary equipment decreases because of adding regenerative turbine. The rise of final feed water temperature is $38.52{ }^{\circ} \mathrm{C}$ and this is significant indicator to decrease fuel consumption. Moreover, exergy efficiency of Case 3 increases $1.31 \%$ compared with Case 2 . This shows that increasing exergy efficiency affects potential work out of power plant. 


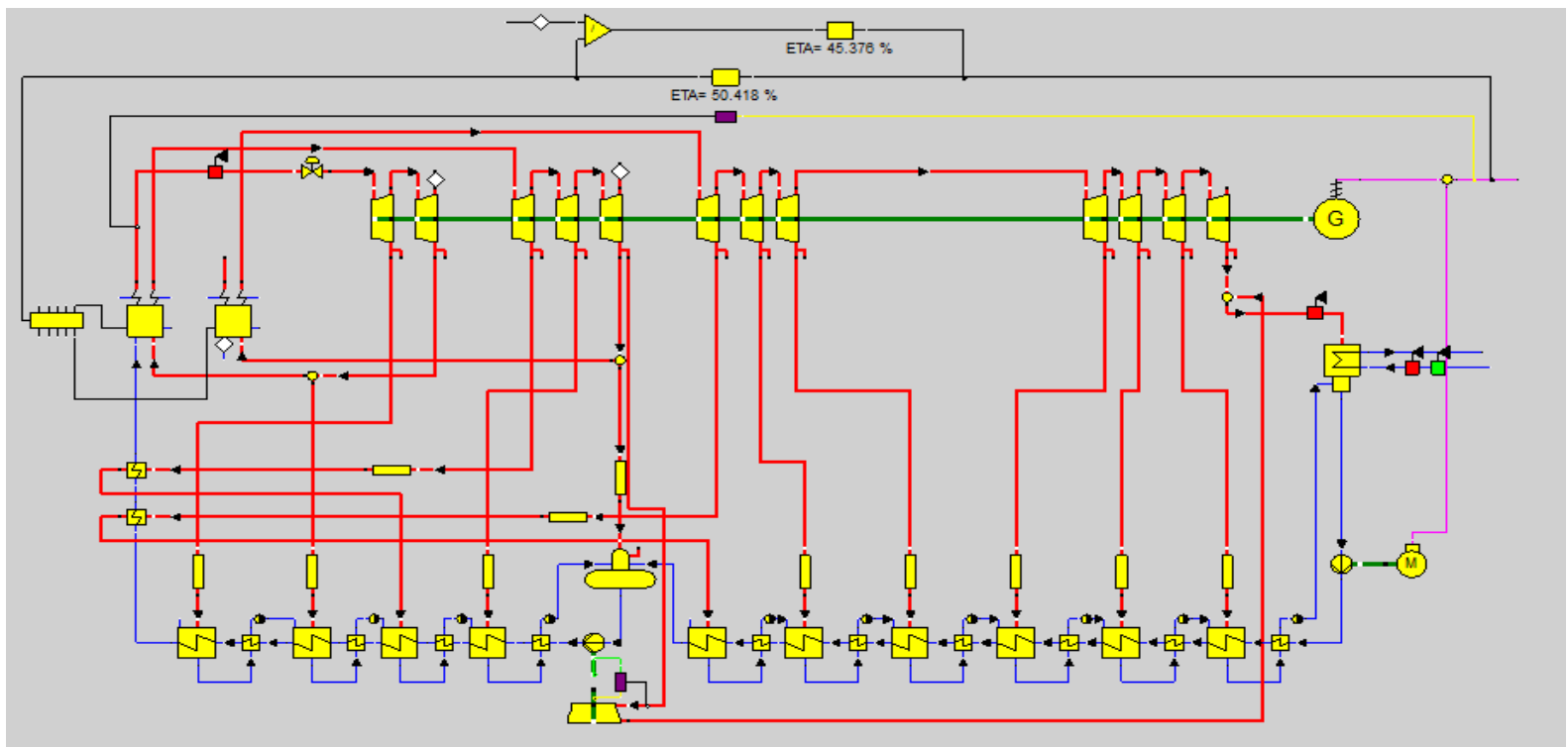

Figure 3. Process diagram of Case 3

Table 3. Energy and exergy performances comparison of Case 2 and Case 3

\begin{tabular}{|c|c|c|}
\hline Performance index & Case 2 & Case 3 \\
\hline Total energy input $(\mathrm{MW})$ & 2279.14 & 2203.78 \\
\hline Power Output $(\mathrm{MW})$ & 1000.00 & 1000.00 \\
\hline Heat rate $(\mathrm{kJ} / \mathrm{kWh})$ & 8204.90 & 7933.60 \\
\hline Decrement in heat rate $(\mathrm{kJ} / \mathrm{kWh})$ & - & 271.29 \\
\hline Power generation efficiency $(\%)$ & 43.876 & 45.376 \\
\hline Efficiency increment $(\%)$ & - & 1.500 \\
\hline Consumption of coal $(\mathrm{kg} / \mathrm{s})$ & 272.95 & 263.92 \\
\hline Total exergy input $(\mathrm{MW})$ & 2611.90 & 2525.55 \\
\hline Exergy efficiency $(\%)$ & 38.28 & 39.59 \\
\hline Exergy efficiency increment $(\%)$ & - & 1.31 \\
\hline Final feed water temperature $\left({ }^{\circ} \mathrm{C}\right)$ & 299.05 & 337.57 \\
\hline
\end{tabular}

\section{DISCUSSION}

The thermal performance of all cases is shown in Figure 4. The thermal and exergy efficiencies of Case 1 are $36.135 \%$ and $31.53 \%$, respectively. Case 1 which is sub-critic consists of single reheat stage, two HPRHs, four LPRHs with one DEA.

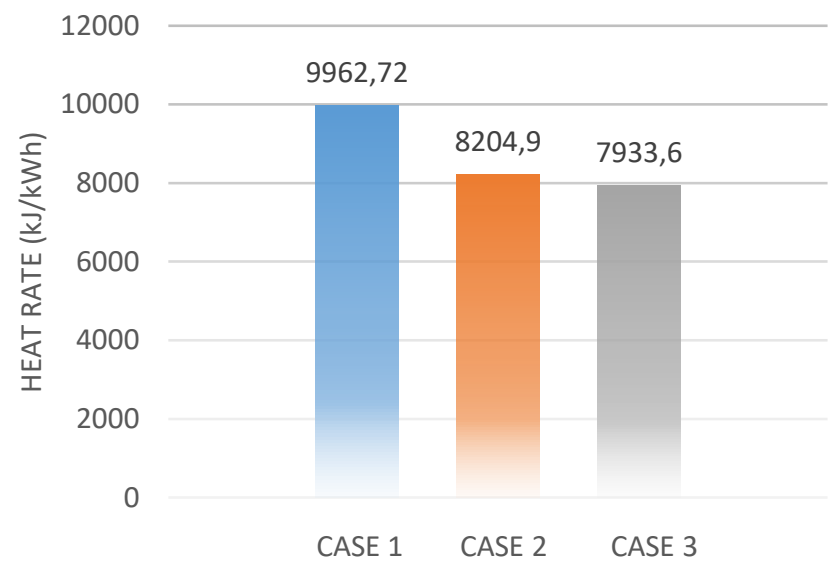

Figure 4. Comparison of the heat rate 
The thermal and exergy efficiencies of Case 2 are $43.876 \%$ and $38.28 \%$, respectively. The thermal and exergy efficiencies of Case 3 are also $45.376 \%$ and $39.59 \%$, respectively. This analysis shows that increasing live steam parameters has significant role for thermal and exergy efficiencies. Furthermore, Case 3 which is operated ultrasupercritical steam parameters comprises of double reheat stage, four HPRHs, six LPRHs with one DEA, two desuperheaters and one regenerative turbine. Final feed water temperature of Case 3 rises $38{ }^{\circ} \mathrm{C}$ compared with Case 2 because of adding two desuperheaters and RHs. After a comprehensive optimization of the double reheat system, the heat rate of the optimized system (Case 3) further decreases by $2029.12 \mathrm{~kJ} / \mathrm{kWh}$ in comparison with that of Case 1.

\section{CONCLUSION}

Coal will continue to widely used as fuel for electricity generation. Although Turkey has a rich coal reserves, nature gas is in used to generate almost half of electricity at Turkey. Huge numbers of sub-critic power plants are built at Turkey. The live steam parameters of power plants at Turkey are around and $550{ }^{\circ} \mathrm{C}[5]$ and their thermal efficiency are between $30 \%$ and $40 \%$ [14].They release great ratio of $\mathrm{CO}_{2}$ and contribute global warming effect. Therefore, optimized double reheat USCPPs are obligation to increase thermal and exergy efficiency and decreases $\mathrm{CO}_{2}$ emission. This study presents comparative energy and exergy analysis of a power plant with sub-critical, super-critical and ultra-supercritical. In this study, three coal-fired power plants were chosen to indicate improvements of energy and exergy efficiencies. Comparative thermodynamic analyses of the three Cases were conducted. Case 3 which involves four HPRHs, six LPRHs, two desuperheaters and one regenerative turbine has the best results compared with Case 1 and Case 2. Because, Case 3 is operated ultrasupercritical steam conditions and it has ten stage steam extraction to increase final feed water temperature. Moreover, Case 3 has higher energy and exergy efficiency and lower fuel consumption compared to Case 1 and Case 2. The results of this study are shown as follows;

(1) Thermal efficiency of Case 3 increases $9.241 \%$ compared with Case 1.

(2) Exergy efficiency of Case 3 increases $8.06 \%$ compared with Case 1.

(3) Fuel consumption of Case 3 reduces $67.47 \mathrm{~kg} / \mathrm{s}$ (20\%) compared with Case 1. $\mathrm{CO}_{2}$ emission decreases on account of reducing fuel consumption. Figure 5 shows the comparison of the energy and exergy efficiency of all Cases.

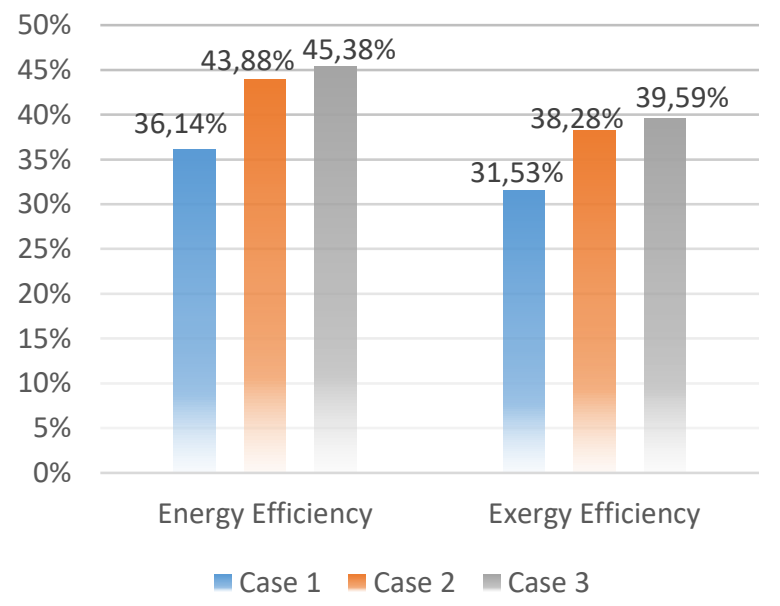

Figure 5. Comparison of the energy and exergy efficiency

Once the efficiency improvement strategy has been applied, it is necessary to take into thermodynamic and economic approach to completely analyses the results. A future suggestion is to study the thermoeconomics of these Cases.

\section{NOMECLATURE}

USCPP Ultra Super-critical Power Plant

HP High Pressure

IP Intermediate Pressure 


$\begin{array}{ll}\text { LP } & \text { Low Pressure } \\ \text { RH } & \text { Regenerative Heater } \\ \text { DEA } & \text { Deaerator } \\ \text { GEN } & \text { Generator } \\ \text { CON } & \text { Condenser } \\ \text { FWP } & \text { Feed Water Pump } \\ \text { LHV } & \text { Lower Heating Value } \\ \eta_{I} & \text { First law efficiency } \\ P_{g e n} & \text { Power generation } \\ E_{\text {total }} & \text { Total energy input per unit time } \\ q & \text { Heat ratio } \\ \varphi & \text { Fuel exergy rate of fuel lower heating value } \\ B_{0} & \text { Fuel exergy value } \\ H_{u} & \text { Fuel lowering heat value } \\ B_{0, \text { solid }} & \text { Solid fuel exergy value } \\ w & \text { Moisture rate of fuel } \\ h_{f g} & \text { Evaporation enthalpy of ambient temperature } \\ \eta_{I I} & \text { Second law efficiency } \\ w_{\text {out }} & \text { Power output } \\ B_{g} & \text { Total exergy input of solid fuel }\end{array}$

\section{REFERENCES}

[1] Sayin, C., Nisa Mencet, M., Ozkan, B. (2005). Assessing of Energy Policies Based on Turkish Agriculture:Current Status and Some Implications, Energy Policy, 332361-2373.

[2] International Energy Agency. World Energy Outlook. (2014).

[3] Adibhatla, S., Kaushik, S.C. (2014). Energy and Exergy Analysis of a Super Critical Thermal Power Plant at Various Load Conditions Under Constant and Pure Sliding Pressure Operation. Applied Thermal Engineering, $73,51-65$.

[4] Utlu, Z. Hepbasli, A. (2007). Assessment of the Turkish Utility Sector Through Energy and Exergy Analyses. Energy Policy 35, 5012-5020.

[5] Erdem, H.H., Akkaya, A.V., Cetin, B., Dagdaş, A., Sevilgen, S.H., Sahin, B., Teke, I., Gungor, C., Atas, S. (2009). Comparative Energetic and Exergetic Performance Analyses for Coal-Fired Thermal Power Plants in Turkey. International Journal of Thermal Sciences 48, 2179-2186.

[6] Xu, G., Zhou, L., Zhao, S., Liang, F., Xu, C., Yang, Y. (2015). Optimum Superheat Utilization of Extraction Steam in Double Reheat Ultra-Supercritical Power Plants. Applied Energy 160, 863-872.

[7] Rashidi, M.M., Aghagoli, A., Ali, M. E. (2014). Thermodynamic Analysis of a Steam Power Plant with Double Reheat and Feed Water Heaters. Advances in Mechanical Engineering.

[8] Aljundi, I.H. (2009). Energy and Exergy Analysis of a Steam Power Plant in Jordan. Applied Thermal Engineering 29, 324-328.

[9] Doseva, N., Chakyrova, D. (2015). Exergy and Energy Analysis of Cogeneration System With Biogas Engines. Journal of Thermal Engineering, 1(3), 391-401.

[10] Luo, Y., Woolley, E. (2015). Improving Energy Efficiency Within Manufacturing by Recovering Waste Heat Energy. Journal of Thermal Engineering, 1(1), 337-344.

[11] Karakurt, A.S., Güneş, Ü. (2017). Performance Analysis of A Steam Turbine Power Plant at Part Load Conditions. Journal of Thermal Engineering, 3(2), 1121-1128.

[12] Akkaya, A.V. (2017). Performance Analyzing of An Organic Rankine Cycle Under Different Ambient Conditions. Journal of Thermal Engineering, 3(5), 1498-1504.

[13] Özdil, N.F., Tantekin, A., Pekdur, A. (2018). Performance Assessment of A Cogeneration System in Food Industry. Journal of Thermal Engineering, 4(2), 1847-1854.

[14] Oktay, Z. (2009). Investigation of Coal-Fired Power Plants in Turkey and a Case Study: Can Plant. Applied Thermal Engineering 29, 550-557.

[15] Kaushik, S.C., Kumar, R. Arora, R. (2016). Thermo-economic Optimization and Parametric Study of an Iirreversible Regenerative Brayton Cycle. Journal of Thermal Engineering, 2, 861-870.

[16] Kumar, R., Kaushik, S. C., Kumar, R. (2015). Performance Analysis of an Irreversible Regenerative Brayton Cycle Based on Ecological Optimization Criterion. International Journal of Thermal \& Environmental Engineering, 9, 25-32.

[17] Aroro, R., Kaushik, S.C., Kumar, R. (2015). Performance Analysis of Brayton Heat Engine at Maximum Efficient Power Using Temperature Dependent Specific Heat of Working Fluid. Journal of Thermal Engineering, $1,345-354$. 
[18] Kaushik, S.C., Manikandan, S., Hans, R. (2016). Energy and Exergy Analysis of an Annular Thermoelectric Heat Pump. Journal of Electronic Materials, 45, 3400-3409.

[19] Kaushik, S.C., Manikandan, S., Hans, R. (2015). Energy and Exergy Analysis of Thermoelectric Heat Pump System. International Journal of Heat and Mass Transfer, 86, 843-852.

[20] Li, Y., Zhou, L., Xu, G., Zhao, S., Yang, Y. (2014). Thermodynamic Analysis and Optimization of a Double Reheat System in an Ultra-Supercritical Power Plant. Energy, 74, 202-214.

[21] Suresh, M. V. J. J., Reddy, K. S., Kolar, A. K. (2011). Thermodynamic Optimization of Advanced Steam Power Plants Retrofitted for Oxy-Coal Combustion. Journal of Engineering for Gas Turbines and Power 133.

[22] Cengel, Y.A., Boles, M.A. 2008. Thermodynamic an Engineering Approach, Fifth Edition.

[23] Tekel, E. (2006). Termik Santrallerin Enerji ve Ekserji Analizi, Pamukkale Üniversitesi. Denizli.

[24] Vardar, N., Yumurtaci, Z. (2010). Emissions Estimation for Lignite-Fired Power Plants in Turkey. Energy Policy, 38, 243-252.

[25] STEAG Energy Services Gmbh. Ebsilon Professional. 2010.

[26] Espatolero, S., Romeo, L. M., Cortes, C. (2014). Efficiency Improvement Strategies for the Feedwater Heaters Network Designing in Supercritical Coal-Fired Power Plants. Applied Thermal Engineering, 73, 449460.

[27] Drbal, L.F., Boston, P. G., Westra, K. L., Erickson, R. B. (1996). Power Plant Engineering by Black\&Veatch.

[28] Zhou, L., Xu, G., Zhao, S., Xu, C., Yang, Y. (2016). Parametric Analysis and Process Optimization of Steam Cycle in Double Reheat Ultra- Supercritical Power Plants. Applied Thermal Engineering, 99, 652-660. 